\title{
PENGARUH MEDIA PEMBELAJARAN DAN KEMANDIRIAN TERHADAP HASIL BELAJAR PENDIDIKAN AGAMA ISLAM
}

\author{
Yasir Al-Harisyah ${ }^{1}$,Harun Sitompul ${ }^{2}$, R. Mursid ${ }^{3}$ \\ ${ }^{1}$ Sekolah Menengah Pertama Plus Darul Ilmi Deli Serdang, Sumatera Utara \\ ${ }^{2,3}$ Pascasarjana Universitas Negeri Medan \\ yasiralharisyah@gmail.com ${ }^{l}$
}

\begin{abstract}
Abstrak: Penelitian ini bertujuan untuk, (1) Mengetahui perbedaan hasil belajar PAI antara siswa yang diajar menggunakan media pembelajaran PowerPoint dengan yang tidak menggunakan PowerPoint. (2) Mengetahui perbedaan hasil belajar PAI perbedaan antara siswa yang memiliki tingkat kemandirian belajar tinggi dengan kemandirian belajar rendah. (3) Mengetahui interaksi antara penggunaan media pembelajaran PowerPoint dan tingkat kemandirian belajar tinggi dan rendah terhadap hasil belajar PAI siswa. Penelitian ini dilakukan pada siswa di SMP Plus Swasta Darul Ilmi Murni terhadap hasil belajar PAI siswa. Teknik Cluster Random Sampling. Metode penelitian quasi eksperimen dengan faktorial $2 \times 2$. Teknik analisis varian dua jalur dengan taraf signifikansi $\alpha=0,05$ dengan Uji $F$, pengujian lanjut Uji Scheffe. Hasil penelitian menunjukkan (1) Hasil belajar PAI siswa yang diajar dengan media pembelajaran Power Point lebih tinggi dibandingkan dengan tidak menggunakan media pembelajaran power point (konvensional), pada taraf signifikansi $\alpha=0,05$ dengan $F_{h}$ sebesar 6,49 dan $F_{\text {tabel }}=4,00$, jadi $F_{\text {hitung }}>F_{\text {tabel }}=6,49>4,00 ;(2)$ hasil perhitungan tentang perbedaan hasil belajar PAI antara kelompok siswa yang memiliki kemandirian belajar tinggi dan rendah pada taraf signifikansi $\alpha=0,05$ dengan $F_{h}$ sebesar 28,15 dan $F_{\text {tabel }}=4,00$ jadi $F_{\text {hitung }}>$ $F_{\text {tabel }}=28,15>4,00$, (3) besarnya rata-rata hasil belajar PAI siswa untuk setiap kelompok pembelajaran $A_{l} B_{1}$ $=91,94$ dan $A_{1} B_{2}=78,59$ sedangkan $A_{2} B_{1}=83,06$ dan $A_{2} B_{2}=79,65$. Hasil perhitungan Anava factorial $2 x 2$ diperoleh hasil perhitungan $F_{h}=8,52$ dan harga tabel $F_{t}=4,00$ adalah $F t_{(0,05)(1,64)}=4,00$, sehingga dapat dinyatakan $F_{h}(8,52)>F_{t}(4,00)$.
\end{abstract}

Kata Kunci: media pembelajaran power point, kemandirian, hasil belajar pendidikan agama islam

\begin{abstract}
This study aims to, (1) Know the differences in PAI learning outcomes between students taught using PowerPoint learning media and those not using PowerPoint. (2) Knowing the differences in PAI learning outcomes the difference between students who have high levels of learning independence with low learning independence. (3) Knowing the interaction between the use of PowerPoint learning media and the high and low levels of learning independence of students' PAI learning outcomes. This research was conducted on students at Darul Ilmi Murni Private Plus Junior High School on PAI student learning outcomes. Random Sampling Cluster Technique. Quasi-experimental research method with factorial $2 \times 2$. Two-way variant analysis technique with a significance level $\alpha=0.05$ with the F test, further testing Scheffe Test. The results showed (1) The learning outcomes of PAI students taught by Power Point learning media were higher than those not using power point learning media (conventional), at a significance level $\alpha=0.05$ with Fh of 6.49 and Ftable $=4$, 00, so Fcount $>$ Ftable $=6.49>4.00$; (2) the results of calculations about differences in PAI learning outcomes between groups of students who have high and low learning independence at a significance level $\alpha=0.05$ with Fh of 28.15 and Ftable $=4.00$ so Fcount $>$ Ftable $=$ 28.15> 4, 00, (3) the average size of PAI student learning outcomes for each learning group A1B1 =91.94 and $A 1 B 2=78.59$ while $A 2 B 1=83.06$ and $A 2 B 2=79.65$. Anava factorial calculation results obtained $2 \times 2$ calculation results $F h=8.52$ and the price table $F t=4.00$ is $F t(0.05)(1.64)=4.00$, so it can be stated Fh (8.52)> Ft (4.00).
\end{abstract}

Keywords: power point learning media, independence, learning outcomes of Islamic religious education

\section{PENDAHULUAN}

Salah satu usaha untuk memberikan motivasi belajar anak adalah dengan menciptakan situasi dan kondisi yang sedemikian rupa agar anak lebih tertarik terhadap setiap pelajaran yang disampaikan oleh guru, dengan kata lain siswa tidak jenuh, tidak bosan ketika proses belajar mengajar. Selanjutnya anak itu merasa butuh terhadap pelajaran yang disampaikan oleh guru tersebut. Pada hakikatnya proses belajar mengajar adalah proses komunikasi, dalam komunikasi sering timbul dan terjadi penyimpanganpenyimpangan sehingga komunikasi tersebut 
tidak efektif dan tidak efisien, antara lain disebabkan kurangnya minat dan kurangnya kegairahan.

Menurut Syukur (2005:123), pembelajaran berbasis masalah (Problem-based Learning) merupakan salah satu strategi pembelajaran yang tepat diaplikasikan di dalam kelas. Untuk dapat membuat siswa minat dalam belajarnya, maka bagi seorang guru dapat memanfaatkan suatu media pembelajaran yang telah ada yang di dalamnya terdapat alat peraga dan media pembelajaran baik yang berupa media berbasis visual, media berbasis audio, media berbasis audio visual, dan lain-lain. Intinya bahwa dalam proses belajar mengajar akan efektif apabila terdapat guru yang professional yang mampu menyelaraskan antara media pendidikan yang ada dengan metode pembelajaran.

Siswa yang memiliki kemandirian dalam belajar akan memperoleh hasil belajar yang lebih baik dibandingkan dengan siswa yang kurang mandiri dalam belajar, karena kemandirian merupakan salah satu hal yang dapat mempengaruhi hasil belajar siswa. Hal ini sesuai dengan yang dikemukan Nursobah (2009: 2) bahwa salah satu hal yang dapat mempengaruhi hasil belajar siswa adalah kemandirian siswa dalam belajar.

Dari beberapa faktor yang mempengaruhi hasil belajar tersebut, penulis meneliti satu faktor saja yaitu kemandirian belajar. Hal ini disebabkan karena dari observasi awal dan wawancara yang penulis lakukan banyak sekali ditemui gejala yang menunjukkan rendahnya hasil belajar siswa diantaranya karena rendahnya kemandirian belajar siswa sehingga kemandirian belajar siswa merupakan salah satu faktor yang menyebabkan rendahnya hasil belajar siswa tersebut.

Kemandirian belajar diartikan sebagai sifat serta kemampuan yang dimiliki siswa untuk melakukan kegiatan belajar aktif, yang didorong oleh motif untuk menguasai sesuatu kompetensi, dan dibangun dengan bekal pengetahuan atau kompetensi yang telah dimiliki. Menurut Haris Mujiman (2007:1), kemandirian belajar dapat diartikan sebagai sifat serta kemampuan yang dimiliki siswa untuk melakukan kegiatan belajar aktif, yang didorong oleh motif untuk menguasai sesuatu kompetensi yang telah dimiliki. Seorang siswa dikatakan mempunyai kemandirian belajar apabila mempunyai kemauan sendiri untuk belajar dan mempunyai tanggung jawab dalam proses belajar, mempunyai rasa percaya diri dalam setiap proses belajar.

Pada umumnya siswa tidak mandiri dalam belajar PAI terlihat saat siswa mengerjakan ulangan masih terdapat siswa yang kurang percaya diri dengan kemampuannya sendiri. Kemandirian belajar dapat terlihat pada kebiasaan-kebiasaan belajar siswa sehari-hari seperti cara siswa merencanakan dan melakukan belajar. Kemandirian belajar yang tinggi dari siswa sangat diperlukan dalam peningkatan hasil belajar PAI karena akan berpengaruh terhadap terciptanya semangat diri untuk belajar.

\section{Hakikat Belajar dan Hasil Belajar PAI}

Belajar merupakan kebutuhan manusia, sebab dengan belajar dapat menjawab keingintahuan. Namun setelah apa yang dipelajari diketahui, keingintahuan itu masih ada dan terus berkembang. Menurut Slameto (2003: 2) "Belajar ialah suatu proses usaha yang dilakukan seseorang untuk memperoleh suatu perubahan tingkah laku yang baru secara keseluruhan, sebagai hasil pengalamannya sendiri dalam interksi dengan lingkungannya“.

Slameto (1999:2) menyatakan bahwa "Secara psikologis, belajar merupakan suatu proses perubahan, yaitu perubahan tingkah laku sebagai hasil dari interaksi dengan lingkungannya dalam memenuhi kebutuhan hidupnya. Perubahan-perubahan itu akan nyata dalam seluruh aspek tingkah laku“.Sehingga pengertian belajar dapat didefenisikan sebagai berikut: "Belajar ialah suatu proses yang dilakukan seseorang untuk memperoleh suatu perubahan tingkah laku yang baru secara keseluruhan, sebagai hasil pengalamannya sendiri dalam interaksi dengan lingkungannya".

Hasil belajar atau bentuk perubahan tingkah laku yang diharapkan meliputi tiga aspek, yaitu: Pertama, aspek kognitif, meliputi perubahanperubahan dalam segi penguasaan pengetahuan dan perkembangan ketrampilan atau kemampuan yang diperlukan untuk menggunakan pengetahuan tersebut. Kedua, aspek afektif, meliputi perubahan-perubahan dalam segi aspek mental, perasaan dan kesadaran. Ketiga, aspek psikomotorik, meliputi perubahan-perubahan dalam segi bentuk-bentuk tindakan motorik (Daradjat, dkk., 2003:197).

Tujuan pembelajaran PAI tertuang dalam standar kompetensi (SK) PAI khususnya 
mata pelajaran Tajjuwid yakni untuk memahami hukum hukum baca Qalqalah, La, Ra. Kemudian, SK tersebut dielaborasi ke dalam kompetensi dasar (KD) antara lain: 1) Menjelaskan bacaan Qalqalah, 2) Menjelaskan la dan Ra, 3) dapat membaca Al- Qur'an dengan baik dan benar sehingga makna dan artinya dari bacaannya tidak salah.. Menurut Muhaimin (2005:40), tujuan-tujuan pendidikan agama Islam dapat dinyatakan sebagai berikut: 1) Pengembangan keimanan dan ketaqwaan kepada Allah SWT. Serta ahklak mulia peserta didik seoptimal mungkin. 2) Penanaman nilai ajaran islam sebagai pedoman mencapai kebahagian hidup didunia dan ahkirat. 3) Penyesuaian mental peserta didik terhadap lingkungan fisik dan sosial. 4) Perbaikan kesalahan-kesalahan, kelemahan-kelamahan peserta didik dalam keyakinan, pengalaman ajaran agama islam dalam kehidupan seharihari. 5) Pencegahan dari hal-hal negatif budaya asing yang dihadapinya sehari-hari. 6) Pengajaran tentang ilmu pengetahuan keagamaan secara umum (alam nyata dan nirnyata) sistem fungsionalnya. 7) Penyaluran untuk mendalami pendidikan agama ke lembaga pendidikan yang lebih tinggi. Pendidikan agama di sekolah bertujuan untuk meningkatkan keyakinan, pemahaman, penghayatan, dan pengamalan siswa tentang agama Islam sehingga menjadi manusia muslim yang beriman dan bertaqwa kepada Allah SWT serta berakhlak mulia dalam kehidupan pribadi, bermasyarakat, berbangsa dan bernegara serta untuk melanjutkan pendidikan pada jenjang yang lebih tinggi (Ramayulis, 2001:103-104 ). Dengan demikain hasil belajar PAI merupakan pelajaran yang memberikan pengetahuan dan membentuk sikap kepribadian, keterampilan dan sikap kebangsaan peserta didik dalam mengamalkan ajaran agama Islam. Pada dasarnya PAI mengkedapankan pembelajaran akidah akhlak dalam kehidupan sehari-hari dalam bermasyrakat.yang ditujukan untuk melaraskan, mengseimbangkan antara iman. Islam dan ihsan. Dalam hasil belajar PAI diharapakan pserta didik dapat memberbaiki perubahan tingkah laku yang diharapkan yang dapat diukur melalui tiga aspek yaitu aspek kognitif, afektif dan psikomotor.

\section{Hakikat Media Pembelajaran Pengertian Media Pembelajaran}

Media apabila dipahami secara garis besar adalah orang, materi atau kejadian yang membangun suatu kondisi yang membuat siswa mampu memperoleh pengetahuan, keterampilan atau sikap. Definisi lain, bahwa media merupakan alat yang digunakan untuk menyalurkan pesan atau informasi dari pengirim kepada penerima pesan (Pupuh, 2007: 65). Gagne (2003:98), menyatakan bahwa media adalah berbagai jenis komponen dalam lingkungan siswa yang dapat merangsang siswa untuk belajar. Sedangkan menurut Anderson sebagaimana dikutip oleh Musfiqon, bahwa media pembelajaran adalah media yang memungkinkan terwujudnya hubungan langsung antara karya seseorang pengembang mata pelajaran dengan para siswa (Musfiqon, 2012: 27). Lebih lanjut Musfiqon (2012: 28), mengemukakan bahwa media pembelajaran dapat didefinisikan alat bantu berupa fisik maupun nonfisik yang sengaja digunakan sebagai perantara antara guru dan siswa dalam memahami materi pembelajaran agar lebih efektif dan efisien. Sehingga materi pembelajaran lebih cepat diterima siswa dengan utuh serta menarik minat siswa untuk belajar lebih lanjut. Pendek kata, media merupakan alat bantu yang digunakan guru dengan desain yang disesuaikan untuk meningkatkan kualitas pembelajaran.

Media yang baik adalah yang dapat memunculkan komunikasi dua arah atau interaktivitas. Semua kegiatan pembelajaran yang akan dikembangkan oleh guru tentu saja memerlukan media yang sesuai dengan tujuan pembelajaran tersebut. Media merupakan alat untuk menyampaikan informasi atau pesan dari suatu tempat ke tempat lain. Menurut I Santyasa (dalam Sahid 2012), proses pembelajaran mengandung lima komponen komunikasi, yakni guru (komunikator), bahan pembelajaran, media pembelajaran, siswa (komunikan), dan tujuan pembelajaran.

Dari pendapat di atas maka disimpulkan media pembelajaran adalah segala sesuatu yang dapat digunakan untuk menyalurkan pesan (bahan pembelajaran), sehingga dapat merangsang perhatian, minat, pikiran, dan perasaan siswa dalam kegiatan belajar untuk mencapai tujuan belajar. Untuk itu agar tercapai kelima komponen komunikasi dalam pembelajaran tersebut maka perlu adanya suatu media pembelajaran yang dapat menjembatani tercapainya proses pembelajaran komunikasi dua arah dengan suasana belajar interaktif, menarik perhatian siswa, mengarahkan siswa agar aktif, efisien dan tanpa 
batas ruang maupun waktu. Selain itu media tersebut juga bisa memberikan rangsangan pada siswa untuk belajar, menjadikan pembelajaran makin efektif dan efisien, dapat menyalurkan pesan secara sempurna, serta dapat mengatasi kebutuhan dan masalah yang dialami siswa dalam belajar. Secara umum media pembelajaran berfungsi untuk memperlancar interaksi antara guru dengan peserta didik sehingga pembelajaran lebih efektif dan efisien. Menurut Rusman (2009: 151), manfaat media pembelajaran adala sebagai berikut (1) penyampaian materi pelajaran dapat diseragamkan, (2) proses pembelajaran lebih jelas dan menarik, (3) proses pembelajaran menjadi interaktif, (4) efisien waktu dan tenaga, (5) meningkatkan kualitas hasil belajar peserta didik, (6) media memungkinkan proses pembelajaran dapat dilakukan dimana saja, dan (7) media dapat menumbuhkan sikap positif peserta didik terhadap materi dan proses belajar.

\section{Pembelajaran dengan Media Komputer} Menurut Russel (1974:1) "individualized instruction is meant who whatever arragment make it possible for each student to be engaged at all times in learning those things that are of most value himself, as an individual", sedangkan Kemp (1994:147) mengemukakan bahwa metode belajar sesuai dengan kecepatan sendiri disebut belajar mandiri, pengajaran sendiri, atau belajar dengan mengarahkan sendiri. Dasar pemikiran pembelajaran individual adalah adanya pengakuan terhadap perbedaan individu masing-masing siswa. Apabila pembelajaran konvensional menekankan pada persamaan, maka pembelajaran individu menekankan perbedaan. Menurut Haryanto (1996:34) pembelajaran individual bertujuan : (1) membantu siswa yang mengalami kesulitan belajar, (2) melayani perbedaan individu siswa dalam belajar dan memperhatikan kepentingan secara individu, (3) meningkatkan mutu dan efektivitas proses pembelajaran,

pelaksanaan pembelajaran yang disesuaikan dengan kemampuan dan minat individu siswa, 5) memberi kesempatan seluas-luasnya pada siswa untuk mengembangkan potensinya secara optimal. Berbagai jenis aplikasi teknologi komputer dalam pembelajaran pada umumnya dikenal dengan istilah Komputer Assisted Instruction (CAI) atau dalam istilah yang sudah diterjemahkan sebagai "pembelajaran berbantuan komputer" (PBK). Menurut Chamber dan Sprecher (1983:3), perangkat ajar atau komputer assisted instruction (CAI) adalah penggunaan komputer yang berbentuk instruksi yang bertujuan untuk pembelajaran yang berjenis driil and practice, tutorial and simulasi. Sedangkan Wadington (1984:354) menyatakan bahwa:

Dari beberapa pendapat di atas dapat disimpulakam bahwa CAI menunjuk pada semua perangkat lunak pembelajaran yang diakses melalui komputer dimana siswa dapat berinteraksi dengan komputer dan pembelajaran CAI sendiri memiliki tujuan pembelajaran berjenis driil and practice, tutorial and simulasi. Keberhasilan penggunaan komputer dalam pembelajaran tergantung berbagai factor seperti proses kognitif dan motivasi belajar. Oleh karena itu prinsip-prinsip perancangan CAI diharapkan dapat melahirkan program yang menarik dan interaktif. Prinsip-prinsip perancangan CAI menurut Arsyad (2005:165169) antara lain: (1) belajar harus menyenangkan, (2) interaktivitas, (3) kesempatan berlatih harus memotivasi, cocok dan tersedia feedback.

\section{Hakikat Kemandirian Belajar Pengertian Kemandirian Belajar}

Moeliono dalam Rina Febriana dan Sarbiran (2001: 57), mengatakan bahwa: "Kemandirian adalah keadaan dapat berdiri sendiri tanpa bergantung pada orang lain." Dalam perkembangannya kemandirian muncul sebagai hasil proses belajar yang dipengaruhi oleh berbagai faktor, diantaranya lingkungan, keluarga, sosial, dan lingkungan sekolah. Keadaan mandiri tidak akan muncul dengan sendirinya bila seseorang tidak belajar. Terlebih lagi kemandirian dalam belajar tidak akan muncul apabila siswa tidak dibekali dengan ilmu yang cukup.

Umar Tirtarahardja \& La Sulo (2000: 50), berpendapat bahwa: "Kemandirian dalam belajar diartikan sebagai aktivitas belajar yang berlangsung lebih didorong oleh kemampuan sendiri, pilihan sendiri dan bertanggung jawab sendiri dari pelajar." Untuk meningkatkan pengetahuan dan keterampilan, tentunya dipengaruhi oleh kemandirian belajar, seperti yang dikemukakan oleh Siahaan (2002), bahwa: "Kemandirian belajar menunjukkan kepada belajar mandiri yang dilaksanakan individu guna meningkatkan pengetahuan sikap dan keterampilan." 
Dengan demikian kemandirian belajar dapat mempengaruhi hasil belajar siswa yang dilakukan tanpa adanya suruhan atau unsure paksaan dari orang lain untuk menguasai sesuatu kompetensi pelajaran. Chickering (Paulina Panen, 2000: 5-10), berpendapat bahwa: "Siswa yang mampu belajar mandiri adalah siswa yang dapat mengontrol dirinya sendiri, mempunyai motivasi yang tinggi, yakin akan dirinya, mempunyai orientasi atau wawasan yang luas dan luwes."

Menurut Ali dan Asrori (2006:56), mengatakan bahwa tingkatan kemandirian beserta ciri-cirinya sebagai berikut: 1) Tingkatan pertama adalah tingkat impulsif dan melindungi diri. Ciri-ciri tingkatan ini adalah: a) Peduli terhadap kontrol dan keuntungan yang dapat diperoleh dari interaksinya dengan orang lain. b) Mengikuti aturan secara oportunistik dan hedonistik.c) Berpikir tidak logis dan tertegun pada cara berpikir tertentu. d) Cenderung melihat kehidupan sebagai zero-sum game. e) Cenderung menyalahkan dan mencela orang lain serta lingkungannya. 2) Tingkatan kedua adalah tingkat komformistik. Ciri-ciri tingkatan ini adalah : a) Peduli terhadap penampilan diri dan penerimaan sosial. b) Cenderung berpikir stereotype dan klise. c) Peduli akan konformitas terhadap aturan eksternal. d) Bertindak dengan motif yang dangkal untuk memperoleh pujian. e) Menyamakan diri dalam ekspresi emosi dan kurangnya introspeksi. f) Perbedaan kelompok didasarkan atas ciri-ciri eksternal. g) Takut tidak diterima kelompok. h) Tidak sensitif terhadap keindividualan. i) Merasa berdosa jika melanggar aturan. 3) Tingkatan ketiga adalah tingkat sadar diri. Ciri-ciri tingkatan ini adalah : a) Mampu berpikir alternatif dan memikirkan cara hidup. b) Peduli untuk mengambil manfaat dari kesempatan yang ada. c) Melihat harapan dan berbagai kemungkinan dalam situasi. d) Menekankan pada pentingnya pemecahan masalah. e ) Penyesuaian terhadap situasi dan peranan. 4) Tingkatan keempat adalah tingkat saksama (conscientious).

Berdasarkan pembatasan masalah di atas, maka rumusan masalah dalam penelitian ini adalah sebagai berikut: (1) Apakah terdapat perbedaan hasil belajar PAI antara siswa yang diajar menggunakan media pembelajaran PowerPoint dengan yang tidak menggunakan PowerPoint pada siswa di SMP Swasta Darul Ilmi Deli serdang?; (2) Apakah terdapat perbedaan hasil belajar PAI perbedaan antara siswa yang memiliki tingkat kemandirian belajar tinggi dengan siswa yang memiliki tingkat kemandirian belajar rendah pada siswa SMP Swasta Darul Ilmi Deli serdang?: dan (3) Apakah terdapat interaksi antara penggunaan media pembelajaran (PowerPoint) dan tingkat kemandirian belajar (tinggi dan rendah) terhadap hasil belajar PAI siswa SMP Swasta Darul Ilmi Deli serdang?

\section{METODE}

Populasi dalam penelitian ini adalah seluruh siswa kelas VIII (delapan) SMP Plus Swasta Darul Ilmi Murni terdiri dari 3 kelas yaitu, kelas VIII Umar 1= 35 Orang, VIII Umar 2= 33 Orang, dan VII Umar 3= 34 orang, dengan jumlah keseluruhan 102 orang dari keseluruhan populasi ditetapkan 2 kelas yang menjadi sampel. masing masing kelas memiliki karakteristik yang sama seperti kurikulum. sampel penelitian diperoleh dengan menggunakan cara cluster random sampling atau teknik pengambilan sampel secara acak sehingga terpilih kelas VIII Umar 1 diajar dengan media pembelajaran power point dan XII Boga 2 diajar dengan tidak menggunakan power point.

Sampel dibagi menjadi dua kelompok berdasarkan tingkat kemandirian belajar yang dimiliki siswa pada setiap kelas.Daritiap kelas sampel masing-masing diambil berdasarkan siswa yang memiliki kemandirian belajar tinggi dan siswa yang memiliki kemandirian belajar rendah. Kemandirian belajar siswa diurutkan dari tingkat yang rendah ketingkat yang tinggi berdasarkan hasil perhitungan jumlah butir angket yang diisi oleh sampel dan diadakan sebelum perlakuan penelitian dimulai.

Metode yang dipergunakan dalam penelitian ini metode quasi eksperimen dengan desain penelitian fakatorial $2 \times 2$. Melalui desain ini akan melibatkan dua kelompok sampel masing masing ditetapkan sebagai kelompok eksperimen dengan menggunakan media pembelajaran power point dan pembelajaran tidak menggunakan media pembelajaran power point dalam pelajaran PAI. Akhir dari eksperimen ini diharapkan mendapat informasi tentang perbedaaan hasil pelajaran PAI melalui media pembelajaran power point dibandingkan dengan tidak media pembelajaran power point. Media pembelajaran power point dan tidak pakai media pembelajaran power point sebagai variable bebas sedangkan kemandirian belajar dibagi menjadi 
kemandirian belajar tinggi dan kemandirian belajar rendah sebagai variable moderator dan hasil belajar pelajaran PAI sebagai variabel
terikat.Berikut ditunjukan variable-variabel tersebut dalam Tabel 1 di bawah ini.

Tabel 1. Desain Penelitian Faktorial

\begin{tabular}{|l|c|c|}
\hline \multirow{2}{*}{ Media Pembelajaran (A) } & \multicolumn{2}{|c|}{ Media Pembelajaran } \\
\cline { 2 - 3 } Kemandirian Belajar (B) & $\begin{array}{c}\text { Media Pembelajaran } \\
\text { Power Point A1 }\end{array}$ & $\begin{array}{c}\text { Media Tidak Menggunakan } \\
\text { Power Point } \\
\text { A2 }\end{array}$ \\
\hline Tinggi (B1) & A1 B1 & A2 B1 \\
\hline Rendah ( B2) & A1 B2 & A2B2 \\
\hline
\end{tabular}

\section{Keterangan:}

A : Media pembelajaran

A 1 : Media pembelajaran Power point

A 2 : tidak pakai media power point

B : Kemandirian

B 1 : Kemandirian tinggi

B 2 : Kemandirian rendah

A1 B1 : Kelompok siswa yang diberikan media pembelajaran power point dengan tingkat kemandirian belajar tinggi.

A1 B2 : Kelompok siswa yang diberikan media pembelajaran power point dengan tingkat kemandirian belajar rendah.

A2 B1 : Kelompok siswa yang diberikan media konvensional dengan tingkat kemandirian belajar tinggi.

A2 B2 : Kelompok siswa yang diberikan media pembelajaran konvensional dengan tingkat kemandirian belajar rendah.

\section{Teknik Analisis Data}

Untuk melakukan analisis data digunakan tehnik analisis varian dua jalur dengan ANAVA 2 X 2 pada taraf signifikan $5 \%$. Sebelum penggunaan analisis varians ada beberapa persyaratan yang harus dipenuhi, yaitu: (1) data yang digunakan berdistribusi normal, maka dilakukan uji normalitas dengan menggunakan uji Liliefors, (2) harus memiliki varians populasi yang homogen maka harus dilakukan uji homogenitas Varians dengan menggunakan uji F dan uji Barlett, (3) jika hasil pengujian signifikan, untuk melihat interaksi antara variabel manipulasi dan variabel moderator terhadap variabel terikat menggunakan uji Scheffe.

Untuk memberi arah dalam analisis data, maka hipotesis perlu dinyatakan dalam rumus statistik. Adapun rumusan hipotesis statistik ini dinyatakan sebagai berikut:

a. Hipotesis pertama :

Ho : $\mu \mathrm{A} 1 \mathrm{~B} 1 \leq \mu \mathrm{A} 1 \mathrm{~B} 2$

$\mathrm{Ha}: \mu \mathrm{A} 1 \mathrm{~B} 1>\mu \mathrm{A} 2 \mathrm{~B} 1$

b. Hipotesa dua:

Ho: $\mu \mathrm{A} 1 \mathrm{~B} 2 \leq \mu \mathrm{A} 2 \mathrm{~B} 2$

Ha $: \mu \mathrm{A} 1 \mathrm{~B} 2>\mu \mathrm{A} 2 \mathrm{~B} 2$

c. Hipotesa tiga:

Ho: $\mathrm{A}$ x B $=0$

$\mathrm{Ha} \quad: \mathrm{A}><\mathrm{B} \neq 0$

Keterangan:

$\mathrm{A}=$ Media Pembelajaran

A $1=$ Media pembelajaran Power Point

A 2 = Media Pembelajaran Konvensional

$\mathrm{B}=$ kemandirian belajar

$\mathrm{B} 1=$ kemandirian belajar tinggi

B2 = kemandirian belajar rendah

$\mu \mathrm{A} 1 \mathrm{~B} 1=$ Hasil belajar PAI yang diajar dengan Media pembelajaran power point dan memiliki kemandirian belajar tinggi.

$\mu \mathrm{A} 2 \mathrm{~B} 1=$ Hasil belajar PAI yang diajar dengan Media Konvensional dan kemandirian belajar tinggi.

$\mu \mathrm{A} 1 \mathrm{~B} 2=$ Hasil belajar PAI yang diajar dengan media pembelajran power point dan memiliki kemendirian belajar rendah

$\mu \mathrm{A} 2 \mathrm{~B} 2=$ Hasil belajar PAI yang diajar dengan media konvensional dan memiliki kemandirian belajar rendah

$\mathrm{AxB}=$ Interaksi antara media

Pembelajaran dengan kemandirian belajar

\section{HASIL DAN PEMBAHASAN Hasil Penelitian}

Untuk keperluan pengujian hipotesis dengan menggunakan teknik analisis anava faktorial 2 x 2 dan uji lanjut Scheffe diperlukan harga rata-rata tiap kelompok, 
berikut ini disajikan data hasil belajar fisika pada Tabel 2. Dari data ringkasan hasil perhitungan varians di dapat varians gabungan yaitu $S^{2}=171,12$ dan $B=104,20$, maka diperoleh $\chi_{\text {hitung }}^{2}=1,61$, dengan $\alpha=0,05$, dari daftar distribusi chi-kuadrat dengan $\alpha=0,05$, dari daftar distribusi chi-kuadrat dengan $\mathrm{dk}=1$ didapat $\chi_{0,95(3)}^{2}=7,81$. Ternyata $\chi_{\text {hitung }}^{2}<\chi_{\text {tabel }}^{2}(1,61<7,81)$ sehingga $\mathrm{H}_{0}$ diterima yang berarti data berasal dari kelompok yang homogen.

Setelah pengujian persyaratan analisis dilakukan, yaitu uji normalitas dan uji homogenitas, maka disimpulkan bahwa persyaratan yang harus dipenuhi oleh data penelitian sehubungan dengan teknik analisis varians telah terpenuhi.

Tabel 2. Rangkuman Data Hasil Perhitungan Analisis Deskriptif

\begin{tabular}{|c|c|c|c|c|}
\hline \multicolumn{2}{|c|}{ Kemandirian Belajar } & \multicolumn{2}{c|}{ Media Pembelajaran } & \multirow{2}{*}{ Total } \\
\cline { 2 - 4 } & $\mathrm{N}$ & $\mathbf{A}_{\mathbf{1}}$ & $\mathbf{A}_{\mathbf{2}}$ & \\
\hline \multirow{4}{*}{ Tinggi $\left(\mathrm{B}_{1}\right)$} & $\sum \mathrm{X}$ & 18 & 16 & 34 \\
& $\sum \mathrm{X}^{2}$ & 1655 & 1329 & 2984 \\
& & 152847 & 111301 & 265270 \\
& $\mathrm{~S}_{\mathrm{i}}{ }^{2}$ & 91,94 & 83,06 & 87,67 \\
& $\mathrm{~N}$ & 37,72 & 56,93 & 47,32 \\
\hline \multirow{4}{*}{ Rendah $\left(\mathrm{B}_{2}\right)$} & $\sum \mathrm{X}$ & 17 & 17 & 34 \\
& $\sum \mathrm{X}^{2}$ & 1336 & 1354 & 2690 \\
& & 105770 & 108366 & 214136 \\
& $\mathrm{~S}_{\mathrm{i}}{ }^{2}$ & 78,59 & 79,65 & 79,12 \\
& $\mathrm{~N}$ & 45,65 & 30,83 & 38,24 \\
\hline \multirow{4}{*}{ Total } & $\sum \mathrm{X}$ & 35 & 33 & 68 \\
& $\sum \mathrm{X}^{2}$ & 2991 & 2683 & 5674 \\
& & 258617 & 219667 & 478284 \\
& $\mathrm{~S}_{\mathrm{i}}{ }^{2}$ & 85,46 & 81,30 & 83,06 \\
& & 41,68 & 43,88 & 42,78 \\
\hline
\end{tabular}

Setelah data diolah dengan anava 2 jalur 2 x 2 maka diperoleh hasil analisis seperti pada Tabel 3

Tabel 3. Ringkasan Hasil Perhitungan ANAVA Faktorial 2 × 2

\begin{tabular}{|l|r|r|r|r|l|l|}
\hline \multicolumn{1}{|c|}{ Sumber Variasi } & Dk & JK & RJK & Fhitung & $\begin{array}{l}\text { Ftabel } \\
\boldsymbol{\alpha}=\mathbf{0 , 0 5}\end{array}$ & Keterangan \\
\hline Media pembelajaran (A) & 1 & 293,11 & 293,11 & 6,49 & 4,00 & Signifikan \\
\hline Kemandirian Belajar (B) & 1 & 1271,88, & 1271,88 & 28,15 & 4,00 & Signifikan \\
\hline Interaksi (AB) & 1 & 66 & 384,66 & 8,52 & 4,00 & Signifikan \\
\hline Galat & 65 & 2889,88 & 45,15 & & & \\
\hline & 68 & 4838,88 & & & & \\
\hline
\end{tabular}

Karena F hitung $>$ Ftabel, dapat disimpulkan adanya interaksi antara Media pembelajaran dengan kemampuan kemandirian belajar terhadap hasil belajar PAI.

Pengujian dilakukan terhadap hipotesis statistik yang dirumuskan sebagai berikut : Ho: $\mu \mathrm{A}_{1} \leq \mu \mathrm{A}_{2}$

$\mathrm{Ha}: \mu \mathrm{A}_{1}>\mu \mathrm{A}_{2}$.

Kriteria pernyataan hipotesis adalah jika $F_{h}>F_{t}$ diterima dan Ho ditolak jika $F_{h}>F_{t}$, maka $\mathrm{Ha}$ ditolak dan $\mathrm{Ho}$ diterima. Hasil perhitungan analisis varians dua jalur dengan 
tentang perbedaan hasil belajar yang diajarkan dengan media pembelajaran PowerPoint $\mathrm{A}_{1}=$ 85,46 dan tidak menggunakan media pembelajaran power point (Konvensional) $\mathrm{A}_{2}=$ 81,30 , di dapat hasil perhitungan $F_{h}$ sebesar 6,49 dan harga $F_{t}$ untuk taraf signifikansi adalah 4,00 dengan derajat kebebasan $\mathrm{dk}_{(1,64)}$ didapat $F_{h}(6,49)>F_{t}(4,00)$, sehingga Ho ditolak dan $\mathrm{Ha}$ diterima. Dengan demikian temuan penelitian menyimpulkan, bahwa hipotesis penelitian $\mathrm{Ha}$ yang berbunyi :Kelompok siswa yang diajar dengan media pembelajaran Power point memperoleh hasil belajar PAI yang lebih tinggi dari siswa yang diajar dengan tidak menggunakan media pembelajaran power point (konvensional), pada taraf kepercayaan $\alpha=0,05$ teruji kebenarannya,.

\section{Hasil Belajar PAI Siswa Yang Memiliki Kemandirian Belajar Tinggi Lebih Tinggi daripada Hasil Belajar PAI Siswa Yang Memiliki Kemandir Belajar Rendah}

Hasil belajar PAI siswa yang memiliki kemandirian belajar tinggi dan kemandirian belajar rendah dilakukan dengan analisa varians (ANAVA). Pengujian dilakukan terhadap hipotesis yang dirumuskan sebagai berikut: Ho : $\mu \mathrm{A}_{1} \mathrm{~B}_{1} \leq \mu \mathrm{A}_{2} \mathrm{~B}_{1} \mathrm{Ha}: \mu \mathrm{A}_{1} \mathrm{~B}_{1}>\mu \mathrm{A}_{2} \mathrm{~B}_{1}$

Kriteria pernyataan hipotesis adalah jika $F_{h}>F_{t}$ diterima dan Ho ditolak jika $F_{h}>F_{t}$ maka Ha ditolak dan Ho diterima. Hasil perhitungan analisis varians tentang perbedaan hasil belajar PAI antara siswa yang memiliki kemandirian belajar tinggi dengan penerapan media pembelajaran PowerPoint rata-rata sebesar $\mathrm{B}_{1}=87,67$ dan untuk tidak menggunakan media pembelajaran power point (konvensional) rata-rata adalah $\mathrm{B}_{2}=79,12$, di dapat hasil perhitungan $F_{h}$ sebesar 28,15 dan harga $F_{t}$ untuk taraf signifikansi adalah 4,00 dengan derajat kebebasan $\mathrm{dk}_{(1,65)}$ didapat $\mathrm{F}_{\mathrm{h}}$ $(28,15)>F_{t}(4,00)$, sehingga Ho ditolak dan $\mathrm{Ha}$ diterima. Dengan demikian temuan penelitian menyimpulkan, bahwa hipotesis penelitian $\mathrm{Ha}$ yang berbunyi :Kelompok siswa yang memiliki kemandirian belajar tinggi memperoleh hasil belajar PAI lebih tinggi dibandingkan dengan kelompok siswa yang memiliki kemandirian belajar rendah telah teruji kebenarannya, pada taraf kepercayaan $\alpha=0,05$.

\section{Interaksi Antara Media Pembelajaran dengan Kemandirian BelajarTerhadap Hasil Belajar}

Pengujian dilakukan terhadap hipotesis statistik yang dirumuskan sebagai berikut :

$$
\begin{aligned}
& \text { Ho: } \mathrm{A}><\mathrm{B}=0 \\
& \text { Ha }: \mathrm{A}><\mathrm{B} \neq 0
\end{aligned}
$$

Kriteria pernyataan hipotesis adalah jika $F_{h}>F_{t}$ diterima dan Ho ditolak jika $F_{h}>F_{t}$, maka Ha ditolak dan Ho diterima. Besarnya rata-rata hasil belajar PAI untuk setiap kelompok pembelajaran adalah sebagai berikut, untuk $\mathrm{A}_{1} \mathrm{~B}_{1}=91,94$ dan $\mathrm{A}_{1} \mathrm{~B}_{2}=78,59$ sedangkan $\mathrm{A}_{2} \mathrm{~B}_{1}=83,06$ dan $\mathrm{A}_{2} \mathrm{~B}_{2}=79,65$. Hasil perhitungan Anava faktorial $2 \times 2$ diperoleh hasil perhitungan $F_{h}=28,15$ dan harga tabel $F_{t}=4,00$ pada taraf kepercayaan $\alpha=$ 0,05 dengan $\mathrm{dk}=(1,64)$ adalah $\mathrm{Ft}_{(0,05)(1,64)}=$ 4,00 sehingga dapat dinyatakan $\mathrm{F}_{\mathrm{h}}(28,16)>$ $\mathrm{F}_{\mathrm{t}}(4,00)$, Dengan demikian temuan penelitian menyimpulkan, bahwa hipotesis peneitian $\mathrm{Ha}$ yang berbunyi : terdapat interaksi antara Media pembelajaran dan kemandirian belajar dalam mempengaruhi hasil belajar PAI SMP Plus Swasta Darul Ilmi Murni Ha diterima dan Ho ditolak pada taraf kepercayaan $\alpha=0,05$ teruji kebenarannya.

Berdasarkan hasil pengujian hipotesis ketiga yang menyatakan adanya interaksi antara media pembelajaran dengan kemandirian belajar, maka perlu dilakukan uji perbedaan rata-rata antara dua proporsi dengan Uji Lanjut Scheffe.

Gambar 1 menunjukkan pengaruh dan interaksi dari Media pembelajaran dan kemandirian belajar terhadap hasil belajar PAI dari siswa SMP Plus Swasta Darul Ilmi Murni, akan tetapi media pembelajaran Power point dominan dibandingkan dengan tidak menggunakan media power point (konvensional).

Dengan kata lain semakin baik media pembelajaran yang diterapkan oleh guru dalam menyampaikan bahan ajar, maka semakin tinggi pencapaian hasil belajanya. Di lain pihak faktor kemandirian belajar perlu diperhatikan karena terbukti bahwa kemandirian belajar berpengaruh terhadap hasil belajar PAI siswa. Hasil pengujian dengan menggunakan Scheffe dapat dilihat dalam Tabel 4 . berikut: 
Tabel 4. Ringkasan Hasil Pengujian dengan Menggunakan Uji Scheffe

\begin{tabular}{|c|c|c|c|}
\hline No & $\begin{array}{c}\text { Hipotesis } \\
\text { Statistik }\end{array}$ & Fhitung & $\begin{array}{c}\text { Ftabel } \\
\alpha=0,05\end{array}$ \\
\hline 1 & $\begin{array}{c}\mathrm{Ho}: \mu \mathrm{A}_{1} \mathrm{~B}_{1}=\mu \mathrm{A}_{2} \mathrm{~B}_{1} \\
\mathrm{Ha}: \mu \mathrm{A}_{1} \mathrm{~B}_{1}>\mu \mathrm{A}_{2} \mathrm{~B}_{1}\end{array}$ & $14,80^{*}$ & 2,76 \\
\hline 2 & $\begin{array}{l}\mathrm{Ho}: \mu \mathrm{A}_{1} \mathrm{~B}_{1}=\mu \mathrm{A}_{1} \mathrm{~B}_{1} \\
\mathrm{Ha}: \mu \mathrm{A}_{1} \mathrm{~B}_{1}>\mu \mathrm{A}_{1} \mathrm{~B}_{2}\end{array}$ & $34,54^{*}$ & 2,76 \\
\hline 3 & $\mathrm{Ho}: \mu \mathrm{A}_{1} \mathrm{~B}_{1}=\mu \mathrm{A}_{2} \mathrm{~B}_{2}$ & $29,28^{*}$ & 2,76 \\
\hline 4 & $\mathrm{Ha}: \mu \mathrm{A}_{1} \mathrm{~B}_{1}>\mu \mathrm{A}_{2} \mathrm{~B}_{2}$ & $3,65^{*}$ & 2,76 \\
\hline 5 & $\mathrm{Ho}: \mu \mathrm{A}_{1} \mathrm{~B}_{2}=\mu \mathrm{A}_{2} \mathrm{~B}_{1}$ & 0,21 & 2,76 \\
\hline 6 & $\mathrm{Ha}: \mu \mathrm{A}_{1} \mathrm{~B}_{2}>\mu \mathrm{A}_{2} \mathrm{~B}_{1}$ & & \\
\hline $\mathrm{Ho}: \mu \mathrm{A}_{1} \mathrm{~B}_{2}=\mu \mathrm{A}_{2} \mathrm{~B}_{2}$ & & 2,76 \\
\hline
\end{tabular}

Keterangan $: *$ signifikan

Untuk memvisualisasikan interaksi dan media pembelajaran dan kemandirian belajar terhadap kemampuan hasil belajar PAI, maka di ambil dari rata-rata dari tiap kelompok data penelitian, dapat digambarkan sebagai berikut :

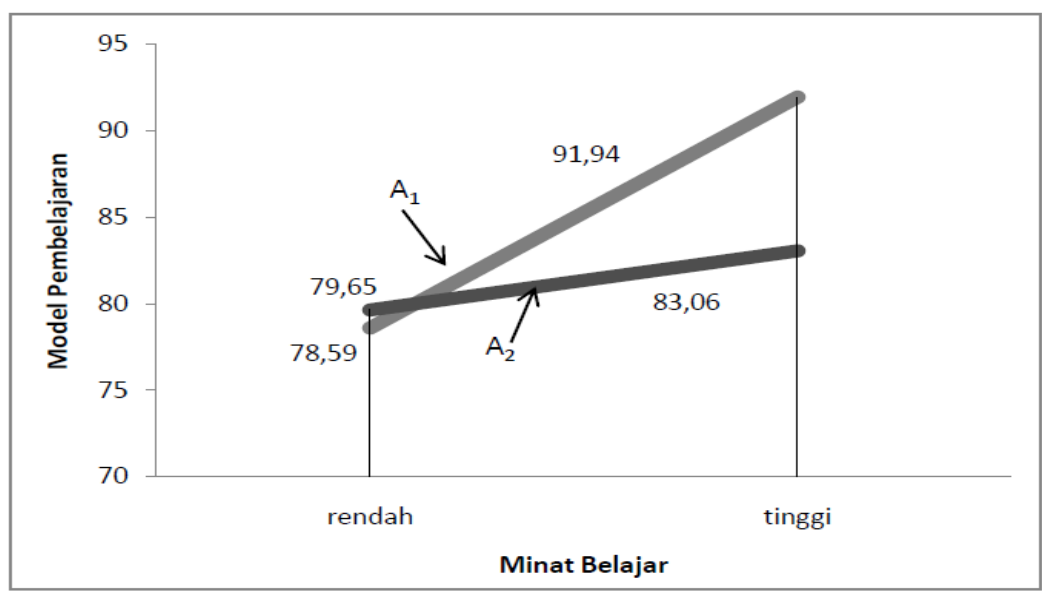

Gambar 1. Interaksi Media Pembelajaran dan Kemandirian Belajar Terhadap Hasil Belajar PAI

Keterangan

$\mathrm{A}_{1}=$ Media pembelajaran PowerPoint

$\mathrm{A}_{2}=$ Media pembelajaran tidak pakai power point (konvesional)

\section{Pembahasan Hasi Penelitian}

Hasil Belajar PAI Siswa Yang

Mengikuti Pembelajaran dengan Media Pembelajaran PowerPoint Lebih Tinggi dari pada Siswa yang Mengikuti Pembelajaran Dengan Tidak Menggunakan Media Power Point (konvesional)

Berdasarkan pengolahan data diperoleh bahwa Hasil belajar PAI siswa yang mengikuti pembelajaran dengan media pembelajaran Power point lebih tinggi dari pada siswa yang mengikuti pembelajaran dengan tidak menggun akan medil pembelajaran power point (konvensional), di mana skor rata-rata Hasil belajar PAI siswa yang mengikuti pembelajaran dengan media pembelajaran Power point lebih tinggi dari pada siswa yang mengikuti pembelajaran dengan media pembelajaran Konvensional. Hal ini disebabkan bahwa media pembelajaran Power point lebih baik dalam meningkatkan pemahaman siswa di bandingkan dengan tidak menggunakan media pembelajaran power point (konvensional) pada taraf signifikansi $5 \%$. Hasil ini menunjukkan bahwa untuk mengajarkan materi ajar PAI lebih baik menggunakan media pembelajaran Power point dibandingkan tidak menggunakan power point 
(konvensional), dibentuk dengan memperhatikan keragaman dan latar belakang. Sedangkan kelompok ahli, yaitu kelompok siswa yang terdiri dari anggota kelompok lain (kelompok asal) yang ditugaskan untuk mendalami topik tertentu untuk kemudian dijelaskan kepada anggota kelompok asal. Disini, peran guru adalah memfasilitasi dan memotivasi para anggota kelompok ahli agar mudah untuk memahami materi yang diberikan.Kunci tipe Power point ini adalah interdependence setiap siswa terhadap anggota tim yang memberikan informasi yang diperlukan. Artinya para siswa harus memiliki tanggunga jawab dan kerja sama yang positif dan saling ketergantungan untuk mendapatkan informasi dan memecahkan masalah yang diberikan.

Power point disini dapat diartikan sebagai perangkat lunak yang paling tersohor yang biasa dimanfaatkan untuk presentasi. Pemanfaatan power point atau perangkat lunak lainnya dalam presentasi menjadi sangat mudah, dinamis, dan sangat menarik. Antara pengertian media pembelajaran dan pengertian Power Point, dapat dipahami bahwa pembelajaran dengan program Power Point adalah suatu media komputer dengan perangkat lunak Power Point yang digunakan oleh guru untuk menyalurkan pesan atau menyamPAIkan materi pelajaran, merangsang pikiran, perasaan, perhatian, dan kemauan siswa melalui indera pendengaran, pengamatan, atau penglihatan dan interaksi antara guru dan murid dalam proses belajar mengajar. Media pengajaran paling besar pengaruhnya bagi indera dan lebih menjamin pemahaman orang yang mendengarkan saja tidaklah sama tingkat pemahamannya dan lamanya bertahan apa yang dipahaminya dibandingkan dengan mereka yang melihat, atau melihat dan mendengarnya.

Keberhasilan proses pembelajaran, sedikit banyak ditentukan oleh kemampuan guru dalam menyajikan pembelajaran. Penyajian pembelajaran yang monoton, seringkali menjadi penyebab bosan siswa-siswi. Agar penyajian materi pembelajaran dapat dipahami siswa, guru perlu menggunakan teknik dan metode yang bervariasi, disamping itu juga perlu menggunakan alat bantu pembelajaran.

Namun, salah satu Media pembelajaran yang masih berlaku dan sangat banyak digunakan oleh guru adalah Media pembelajaran konvensional. Media ini sebenarnya sudah tidak layak lagi kita gunakan sepenuhnya dalam suatu proses pengajaran, dan perlu diubah. Tapi untuk mengubah media pembelajaran ini sangat susah bagi guru, karena guru harus memiliki kemampuan dan keterampilan menggunakan Media pembelajaran lainnya.

Memang, dengan tidak menggunakan media pembelajaran power point (kovensional) ini tidak serta merta kita tinggal, dan guru mesti melakukan media konvensional pada setiap pertemuan, setidak-tidak pada awal proses pembelajaran di lakukan. Atau awal pertama kita memberikan kepada anak didik sebelum kita menggunakan media pembelajaran yang akan kita gunakan. Menurut Djamarah (1996) metode pembelajaran konvensional adalah metode pembelajaran tradisional atau disebut juga dengan metode ceramah, karena sejak dulu metode ini telah dipergunakan sebagai alat komunikasi lisan antara guru dengan anak didik dalam proses belajar dan pembelajaran. Dalam pembelajaran sejarah metode konvensional ditandai dengan ceramah yang diiringi dengan penjelasan, serta pembagian tugas dan latihan.

Hasil Belajar PAI Siswa Yang Memiliki Kemandirian Belajar Tinggi Lebih Tinggi dari Pada Hasil Belajar PAI Siswa Yang Memiliki Kemandirian Belajar Rendah

Hasil penelitian menunjukkan bahwa hasil belajar PAI siswa yang memiliki kemandirian belajar tinggi, yang mengikuti pembelajaran dengan media pembelajaran Power point lebih tinggi dari pada siswa yang mengikuti pembelajaran dengan tidak menggunakan media pembelajaran power point (konvensional). Hal ini berindikasi bahwa siswa yang memilki kemampuan kemandirian belajar tinggi lebih mampu memahami materi pelajaran PAI dibandingkan siswa yang memiliki kemandirian belajar rendah.

Kemandirian belajar adalah sesuatu keinginan atau kemauan yang disertai perhatian dan keaktifan yang disengaja yang melahirkan rasa senang dalam perubahan tingkah laku, baik berupa tingkah laku,sikap serta ketrampilan. memiliki unsur afeksi, kesadaran sampai pilihan nilai, pengerahan perasaan, seleksi, keinginan, dan kecenderungan untuk berbuat terhadap sesuatu.

Winkel (2004) mengemukakan bahwa kemandirian belajar adalah suatu kerangka mental yang terdiri dari kombinasi gerak perpaduan dan campuran dari perasaan, 
prasangka, cemas dan kecenderungankecenderungan, lain yang biasa mengarahkan individu kepada suatu pilihan tertentu. Ahmadi (1992:34) mengemukakan ada tiga aspek-aspek yang mempengaruhi kemandirian belajar antara lain: (1) latihan kebiasaan. Apabila sering melakukan suatu latihan terhadap sesuatu maka akan menyebabkan sesuatu hal tersebut akan menjadi suatu kebiasaan walaupun awalnya merasa tidak ada kemandirian namun karena selalu dilatih akan lebih mudah menimbulkan kemandirian pada suatu objek, keterbiasaan akan menimbulkan keterampilan dan kesenangan melakukannya, (2) kebutuhan. kebutuhan terhadap sesuatu akan memungkinkan timbulnya kemandirian terhadap objek tertentu. Kebutuhan ini akan menjadi pendorong bagi individu untuk mengetahui sesuatu objek yang dijadikan suatu kebutuhan sehingga dapat timbulnya kemandirian untuk mengetahui lebih jauh tentang objek tersebut karena adanya kaitan terhadap diri sendiri, dan (3) ketentuan rangsangan dari objek itu sendiri. Apabila rangsangan kuat dari sesuatu objek maka hal ini berpengaruh besar untuk menarik perhatian dan kemandirian yang datang dari dalam diri individu juga akan semakin meningkat dalam melaksanakan sesuatu objek yang dapat menarik perhatiannya tersebut.

Hasil penelitian yang dilakukan Chalid (2010) secara konsisten menunjukkan bahwa kemandirian belajar dapat mempengaruhi hasil belajar siswa. Usaha yang dapat dilakukan untuk membina kemandirian anak agar menjadi lebih produktif dan efektif antara lain sebagai berikut: (1) memperkaya ide atau gagasan, (2) memberikan hadiah yang merangsang, (3) berkenalan dengan orang-orang yang kreatif, (4) petualangan dalam arti berpetualangan ke alam sekeliling secara sehat, mengembangkan fantasi., (6) melatih sikap positif. Untuk meningkatkan kemandirian belajar anak dapat dilakukan sebagai berikut:(1) hadiri oleh orang-orang yang harus dikenal, membaca artikel yang belum pernah dibaca dan membawa hobbi dan olahraga yang beraneka ragam, hal ini akan membuat lebih berkemandirian, (2) latihan dan praktek sederhana dengan cara memikirkan pemecahanpemecahan masalah khusus agar menjadi lebih berkemandirian dalam memecahkan masalah khusus agar menjadi lebih berkemandirian dalam memecahkan persoalan-persoalan, .membuat orang lain supaya lebih mengembangkan diri yang pada hakekatnya mengembangkan diri sendiri.Dalam pembelajaran kewirausahaan, siswa dihadapkan dengan materi-materi yang menuntut tidak hanya hafalan tetapi juga pemahaman. Dengan demikian siswa yang mempunyai kemandirian untuk terus memahami materi akan mendapatkan prestasi yang baik.

Guru sangat penting mengetahui kemandirian belajar siswa, sehingga dapat memberikan media pembelajaran yang sesuai dengan kemandirian belajar dan dapat memotivasi siswa untuk belajar yang berakibat meningkatkan hasil belajar PAI. Penerapan media pembelajaran Power Point bagi siswa yang memiliki kemandirian belajar tinggi akan mampu mengatasi kesulitan pada siswa dalam memahami materi pelajaran. kemandirian belajar tinggi akan mampu membantu siswa dalam mendorong untuk melakukan suatu kegiatan yang lebih baik sehingga dapat mencapai suatu kesuksesan. kemandirian belajar tinggi jika diajarkan dengan media pembelajaran Power Point akan lebih tepat untuk menumbuhkan kemandirian belajar siswa yang berakibat meningkatkan hasil belajar PAI. Sedangkan bagi siswa yang memiliki motif berprestasi rendah kurang mampu berinteraksi bila diajar dengan media pembelajaran Power Point. Media pembelajaran power point berupaya untuk dapat menggali pengetahuan kita untuk mampu mengusai materi tentang bagaimana PAI sesungguhnya sesuai dengan pandangan dan pengalaman kita sendiri.

Pada umumnya siswa yang memiliki kemandirian belajar rendah kurang mampu dalam hal memanfaatkan sumber belajar yang ada, memecahkan masalah pembelajaran, kurang bertanggung jawab terhadap setiap pakerjaan, puas dengan hasil pekerjaan atas usaha orang lain. Disamping itu siswa lambat dalam mengambil suatu keputusan dan melaksanakannya dalam pembelajaran peluang usaha karena diperlukan ide-ide dan motifasi serta gigih dan giat mencara cara yang kreatif untuk menyelesaikan tugas sekolahnya.

Siswa yang memiliki kemandirian tinggi menggunakan konsep dalam menganalisis suatu informasi bersifat logis, rasional dan intelektual. Siswa yang kemandirian belajarnya tinggi lebih suka terlibat dalam pembelajaran dan selalu ingin mengetahui sebab-sebab dari suatu persoalan sedangkan siswa yang kemandirian belajarnya rendah mengupayakan bantuan dan arahan dari 
orang lain. Dengan kata lain, siswa yang kemandirian belajar rendah tidak siap kalau belajar menemukan sendiri cenderung suka belajar mengandalkan kelompok. Mereka tidak berusaha mendapatkan kesempurnaan dari pekerjaan mereka tahap demi tahap.

Dengan melihat karakteristikkarakteristik antar siswa yang memiliki kemandirian belajar tinggi dan siswa yang memiliki kemandirian belajar rendah bila dikaitkan dengan hasil belajar PAI yaitu dapat berfikir secara logis, kritis, cermat, efisien, dan efektif, maka kemandirian belajar yang tinggi cenderung untuk menguasai materi lebih cepat dari temannya. Dengan demikian diduga hasil belajar PAI SMP Plus Swasta Darul Ilmi Murni, siswa yang kemandirian belajar belajar tinggi lebih tinggi dari pada siswa yang kemandirian belajarnya rendah.

Temuan penelitian ini mengindikasikan bahwa pembelajaran melalui media pembelajaran Power point mampu meningkatkan hasil belajar PAI yang memiliki kemandirian belajar rendah. Siswa yang memiliki kemandirian belajar rendah cenderung kurang mampu untuk menelaah dan mempelajari lebih mendalam lagi mengenai materi PAI yang artinya siswa tersebut tidak memiliki kemampuan untuk berprestasi dari siswa yang lain.

Interaksi Antara Media Pembelajaran dengan Kemandirian Belajar Terhadap Hasil Belajar

Hasil penelitian menunjukkan bahwa interaksi antara Media pembelajaran dengan kemandirian belajar terhadap hasil belajar PAI SMP Plus Swasta Darul Ilmi Murni. Siswa yang memilki kemandirian belajar tinggi dengan mengikuti Media pembelajaran Power point hasil belajarnya lebih tinggi, dibandingkan siswa yang memiliki kemandirian belajar tinggi dengan mengikuti media pembelajaran tidak pakai power point. Demikian pula siswa yang memilki kemandirian belajar rendah dengan mengikuti media pembelajaran power point lebih tinggi, dibandingkan siswa yang memiliki kemandirian belajar rendah dengan mengikuti media pembelajaran tidak pakai power Point. Hal ini mengindikasikan adanya interaksi antara media pembelajaran dengan kemandirian belajar terhadap hasil belajar.

Pendidikan agama Islam (PAI) adalah upaya sadar dan terencana dalam menyiapkan peserta didik untuk mengenal, memahami, mengayati, hingga mengimani ajaran agama Islam, dibarengi dengan tuntutan untuk menghormati penganut agama lain dalam hubungannya dengan kerukunan antar umat beragama hingga terwujud kesatuan dan persatuan bangsa.

Kegiatan PAI diarahkan untuk meningkatkan keyakinan, pemahaman, penghayatan, dan pengamalan terhadap peserta didik, yang di samping untuk membentuk kesalehan atau kualitas pribadi, juga sekaligus untuk membentuk kesalehan atau kualitas pribadi, juga membentuk kesalehan sosial.

Menurut Zakiyah Darajdat (1989; 87) yang dikutip oleh Abdul Majid dan Dian Andayani, "Pendidikan agama Islam adalah suatu usaha untuk membina dan mengasuh peserta didik agar senantiasa dapat memahami ajaran Islam secara menyeluruh, lalu menghayati tujuan, yang pada akhirnya dapat mengamalkan serta menjadikan Islam sebagai pandangan hidup.

\section{PENUTUP}

Berdasarkan hasil penelitian dan pembahasan yang telah dikemukakan sebelumnya, maka dapat disimpulkan

1. Hasil belajar PAI siswa Kelas VIII SMP PLUS Darul Ilmi Murni Deli Serdang yang diajar dengan media pembelajaran Power point lebih tinggi dibandingkan hasil belajar PAI yang diajar dengan tidak menggunakan power point ( konvensional )

2. Secara keseluruhan, siswa yang memilki kemandirian belajar tinggi lebih tinggi hasil belajar PAI siswa Kelas VIII SMP PLUS Darul Ilmi Murni Deli Serdang, dibandingkan dengan siswa yang memilki kemandirian belajar rendah.

3. Terdapat interaksi antara media pembelajaran dan kemandirian belajar siswa terhadap hasil belajar PAI siswa Kelas VIII SMP PLUS Darul Ilmi Murni Deli Serdang.

\section{DAFTAR PUSTAKA}

Ahmadi. (2002). Islam Sebagai Paradigma Ilmu Pendidikan, Semarang: Aditya Media dengan IAIN Walisongo Press.

Ali, M. \& Asrori, M.(2006). Psikologi Remaja, Perkembangan Peserta Didik. Jakarta: Bumi Aksara.

Arsyad, Azhar. 2005. Media Pembelajaran, Jakarta: PT. Raja Grafindo Persada. Cet. 6. 
Chalid, Achmadi, Adi. Narbuko,. (2010) Metodologi Penelitian. Jakarta: Bumi Aksara.

Chambers,Jack A. dan Sprecher, Jerry W.(1983). Computer Assited Instruction: Its Use in the classroom. Prentice Hall, Inc, New Jersey. http://www.library.upnvj.ac.id/pdf /s1teknikinformatika09/202511016/BAB III.pdf. diakses 23 November 2011

Daradjat, Zakiah, dkk. (2003). Metodik Khusus Pengajaran Agama Islam, Jakarta: Bumi Aksara. Cet. I.

Daradjat, Zakiah. (1989). Problema Remaja di Indonesia. Jakarta: Bulan Bintang.

Djamarah. (2002). Strategi Belajar Mengajar, Jakarta: PT. Rineka Cipta. Cet. 3.

Gagne E.D. (1985). The Cognitive Psychology of School Learning. Boston : Little Brown

Haris Mudjiman, (2007), Belajar mandiri, Surakarta, LPP dan UNS Press.

Haryanto, Dedi M. Y. (2002). Pengaruh faktorfaktor Individual Dalam Penggunaan Sistem Informasi Berbasis Komputer Terhadap Kinerja Karyawan. Jurnal Akuntansi dan Bisnis, Vol.2, No.1, Pebruari, Hal 14-25.

Musfiqon. (2012). Pengembangan Media Belajar Dan Sumber Belajar. Jakarta : Prestasi Pustakakarya.

Nursobah, Asep. 2009. Hubungan Antara Kemandirian Belajar, Komunikasi Interpersonal dan Identitas Sosial dengan Hasil Belajar Agama islam. Jurnal. Bandung: UIN Sunan Gunung Djati. Pascasarjana Universitas Negeri Yogyakarta.
Paulina Panen. (2000) .Belajar Mandiri(Mengajar di Perguruan Tinggi).PAUPPAI.Dirjen ikti.depdikbud

Pupuh. Fathurrohman, (2007). Strategi Belajar Mengajar. Bandung: PT Refika Aditama.

Ramayulis. (2001). Metodologi Pengajaran Agama Islam. Jakarta: Kalam Mulia.

Rina Febriana dan Sarbiran. (2001)."Pengaruh Kemandirian dan Kemampuan Menyesuaikan Diri terhadap Prestasi Belajar Siswa Full Day School"Jurnal Penelitian dan Evaluasi No.4 Tahun Ke3.Program

Rusman, (2009). Manajemen Kurikulum. Jakarta : Rajawali Press.

Rusman. (2013). Faktor-faktor yang mempengaruhi hasil belajar. Jakarta: PT. Bumi Aksara.

Russel, B.,H 1988, Introduction to Seismic Inversion Methods: Soc.Explor. Geophysicist, Course NoteSeries, v.2.

Russel, B.,H (1996), Introduction to Seismic Methods, SEG-USA.

Russell, B (1998). A simple seismic imaging exercise. The Leading Edge 17, p 885.

Siahaan, Sudirman. (2002). E-Learning (Pembelajaran Elektronik) Sebagai Salah Satu Alternatif Kegiatan Pembelajaran . http://www.balitbang.org.

Slameto. (1999). Belajar dan Faktor-faktor yang Mempengaruhinya, Jakarta: PT Rineka Cipta, Cet. 3.

Syukur, Fatah. (2005). Teknologi Pendidikan, Semarang: RaSAIL. Cet. 1.

Umar Tirtarahardja \& La Sulo.(2000). pengantar Pendidikan. Jakarta : Rineka Cipta

Winkel. WS, (2004). Psikologi Pengajaran, Jakarta: Gramedia, 1989. 